This item was submitted to Loughborough's Institutional Repository (https://dspace.lboro.ac.uk/) by the author and is made available under the following Creative Commons Licence conditions.

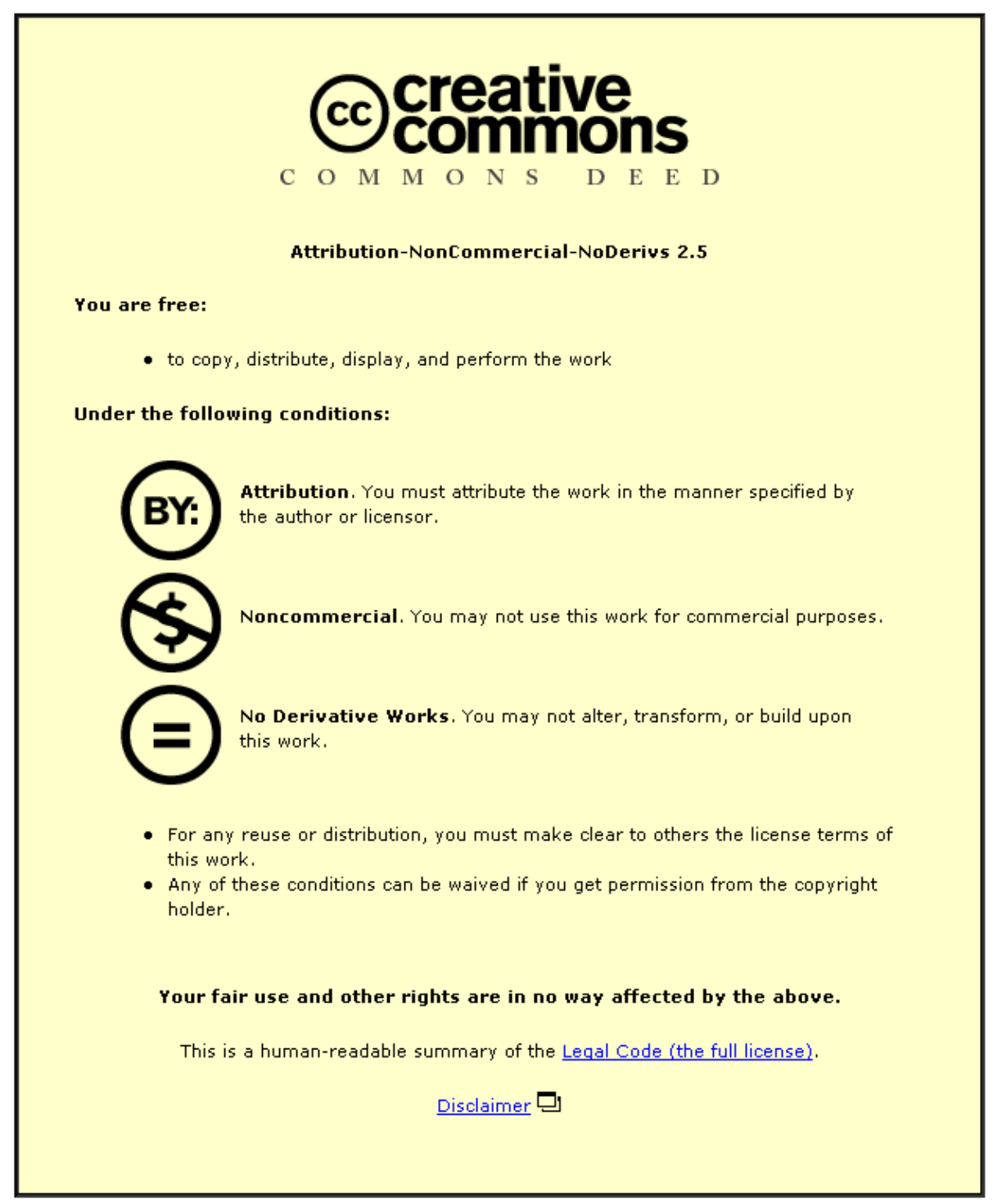

For the full text of this licence, please go to: http://creativecommons.org/licenses/by-nc-nd/2.5/ 


\section{DEVELOPMENT OF THE MATHEMATICS TEACHER EDUCATOR AND ITS RELATION TO TEACHING DEVELOPMENT}

Volume 4 of this Handbook has dealt uniquely with the mathematics teacher educator as a developing professional. This chapter brings Volume 4 to a close by drawing out themes and issues running through the 16 chapters. These include forms of knowledge, theoretical frames, modes of activity and mediational structures in mathematics teacher and teacher educator development, critical inquiry in development and research, and interactions and inter-relationships between teachers and educators. Collaborative partnerships between teachers and educators are seen to provide powerful potential for mutual development.

\section{INTRODUCTION}

Mathematics teaching is complex. Teachers need to know mathematics, pedagogy related to mathematics, mathematical didactics in transforming mathematics into activity for learners in classrooms, elements of educational systems in which teachers work including curriculum and assessment, and social systems and cultural settings with respect to which education is located. In addition, teachers know intimately the students with whom they work and the particularities of the schools where teaching takes place. Each of these elements can be discussed in its own right as if it is independent of the others. For example, pedagogy related to mathematics can be considered separately from social systems and cultural settings with respect to which education is located. In fact what happens in practice is a complicated, dependent interweaving of these elements related to the particularities of context in which teaching takes place. Each teacher, and teachers as local or global communities, work(s) within this complexity and experience(s) the interweaving as part of their professional identity drawing on knowledge tacit or explicit ${ }^{1}$.

Mathematics teacher educators work with teachers to develop teaching. Both educators and teachers have a common aim to provide better learning opportunities for students learning mathematics. Educators provide courses, summer institutes, professional events of various kinds to enable practising teachers to develop knowledge in the areas indicated. Educators work with teachers in school settings, encouraging a professional dialogue about teaching and using their own knowledge

Jaworski, B., \& Wood, T. (Eds.) (2008). International handbook of mathematics teacher education: Vol. 4 The mathematics teacher educator as a developing professional. Rotterdam, The Netherlands: Sense Publishers. 00-00. (C) 2005 Sense Publishers. All rights reserved. 
to promote forms of practice conducive to students' learning. Educators work with prospective teachers, both in and out of the school setting, to develop knowledge of teaching and to enable the newcomers to grow into professional practice. Thus, the kinds of knowledge needed by teachers are also fundamental to the work of teacher educators. While they cannot know the students and context of each school in any depth, educators bring a profound understanding of mathematics, didactics, pedagogy and systemic factors related to a range of settings. Their pedagogic knowledge extends to creation of opportunity for teachers to learn and develop mathematics teaching. In addition, educators need a knowledge of the professional and research literature relating to the learning and teaching of mathematics, knowledge of theories of learning and teaching, and knowledge of methodologies of research that inquires into learning and teaching in schools and educational systems. I used the diagram in Figure 1 in my introductory chapter to this volume.

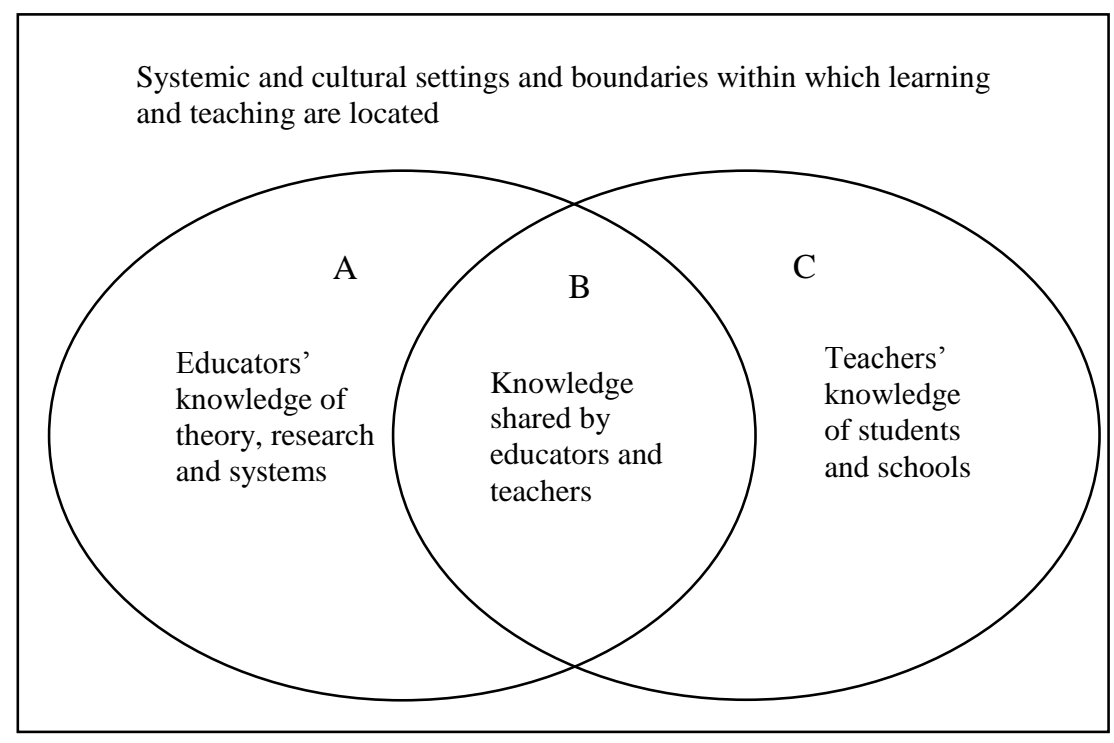

Figure 1. Knowledge in teacher education

A diagram such as we see in Figure 1 apparently simplifies complexity. I use it for three main reasons:

1. To emphasise that knowledge of mathematics teachers and teacher educators is deeply related, although there are specialist areas and of course differences between what is known by individuals or groups in the various areas.

2 To emphasise a common enterprise: all are concerned with the mathematical education of students and all seek to know more about how to provide for the diversity of learning needs. 
3 To emphasise that teacher educators are not all-knowing. They bring knowledge to the enterprise, as teachers do, and this knowledge also has to be tested in practical settings and developed through practice.

Traditionally, teacher education has been seen as a transfer of knowledge from educator to teacher. Educators, in out of school settings, pass on knowledge about mathematics, pedagogy etc. in courses and other programmes and teachers use this knowledge in the arena of classrooms. Or, educators work with teachers in schools, supporting teachers in developing their expertise in the classroom. The traditional view sets up a hierarchy in which educators are superior in knowledge and teachers learn from the educators. Implicit in this perspective is that there will be a similar hierarchy between teachers and their students.

In a constructivist frame, common particularly in teacher education programmes in the 1980s and 1990s (Jaworski \& Wood, 1999), educators recognise teachers as independent cognisers, constructing knowledge of mathematics teaching through their experiences whether in courses or classrooms and through processes of assimilation, accommodation and reflective abstraction (Piaget, 1950). As a consequence, educators seek to provide relevant experiences from which teachers can construct the knowledge they need. Unlike the traditional view there is no expectation that teachers will develop knowledge as conceived by educators and this creates a source of issues as educators seek access to teachers' conceptions to perceive outcomes from teacher education initiatives. Explicit in this perspective on teacher education is that teachers see students also as constructors of knowledge: in their professional learning settings educators use well documented strategies to foster teachers' perspectives relating to students' growth of mathematics knowledge ${ }^{2}$. The constructivist perspective raises many issues for teaching and teacher education (e.g. Carter \& Richards, 1999; Irwin and Britt, 1999). Not least, both teachers and educators grapple with the creation of opportunity for learners' construction of relevant knowledge and the issues that arise when the provider of the experience is not satisfied with the apparent constructions that emerge. Here also the educator/teacher is positioned as provider and evaluator, superior to the learner.

The recognition of issues in traditional and constructivist frames begs some reframing of perspective, and I see the chapters in this volume to an extent, collectively, providing this reframing. In Chapter 1, I hinted at a "shift"

in tone and nuance in the ways educators write about educating teachers. There is less of a surety of models of practice that educators promote with teachers and much more a sense of uncertainty in inquiry. With this uncertainty comes, almost paradoxically, a strength of purpose, new ways of speaking about mathematics teacher education, and new paradigms of practice. These build on notions of reflection, for both teachers and teacher educators, on teacher-as-researcher and simultaneously educator-asresearcher models, and on growing recognitions of epistemology, of complexity and the importance of not trying to oversimplify. 
A multiplicity of paradigms has become evident in the literature; particularly, sociocultural approaches have now become more widely used and discussed. However, the shift is not from the constructivist to the sociocultural, but rather to a recognition that different lenses on practice can afford different ways of seeing and doing, and that we can learn as a community from them all. In this volume, with the teacher educator in focus, we have looked particularly at ways in which teacher educators view the enterprise of mathematics teacher education, and moreover, how teacher educator knowledge and understanding grows alongside the concomitant growth of knowledge for teachers. Coming back to Figure 1, educators have a responsibility for the development of knowledge in areas B and $\mathrm{C}$, and this includes their own knowledge in B. They use knowledge in A, which also grows through their engagement in research. I return to these areas from a perspective on teachers' knowledge later in the chapter.

The various chapters in this volume have inspected and analysed the nature of mathematics teacher educators' knowledge and its growth as part of their educative practice in working with teachers. Chapters take different theoretical perspectives and epistemological positions relating to teacher education programmes and practices. In my next main section I offer a synthesis of themes and issues distilled from these chapters.

\section{MATHEMATICS TEACHER EDUCATOR (MTE) KNOWLEDGE AND ITS GROWTH}

The chapters of Volume 4 tell many stories, and readers will see their own stories in the chapters and in the volume as a whole. In working with the authors on the chapters, I also have my own stories which will permeate my synthesis here. I have organised this under a series of headings as follows:

- Learning in and from practice - mediation and synthesis

- Categorisations of teacher knowledge leading to MTEs' structuring of programmes

- Perception, conception, attention and awareness

- The teaching problem

- Sociocultural views on teacher and MTE learning

- Ethical and moral perspectives in mathematics teacher education: caring and reciprocity

- Growth of knowledge through reflection, inquiry, research and writing

I start from the practice of being a teacher educator and refer to theoretical models which teacher educators have themselves synthesised from reflection on and analyses of their own practice. This leads to a consideration of teacher educator knowledge and ways in which knowledge is conceptualised and made available for teacher education programmes and courses. In such courses teacher educators have goals for teachers' learning, but achieving those goals is not straightforward. Different theoretical perspectives offer alternative conceptualisations of the problems and their resolution. This brings me to what I call "The teaching 
problem": it is the problem of how any one person or group of people can promote or achieve the learning of others and how different theories address this problem. In such promotion there are many ethical and moral issues, particularly in the kinds of relationships that are fostered between teacher educators and teachers. Collaboration between educators and teachers, especially in programmes where both are engaged as researchers is seen as one fruitful way forwards. The activities of a teacher educator research community, particularly in terms of reading the literature and writing for publication, are analysed as important mediators in teacher educator learning and their relation to teacher learning.

\section{Learning in and from practice - mediation and synthesis}

Two models relating to growth of knowledge through practice are offered respectively by Pat Perks and Stephanie Prestage [13] ${ }^{3}$ and by Orit Zaslazvsky [5]. The first model, illustrated in Figures $2 \mathrm{a}$ and $2 \mathrm{~b}$, relates teacher and MTE knowledge. It suggests a knowledge base for teachers followed by an expansion of this for teacher educators who, like the authors of the model, have themselves formerly been mathematics teachers. In this model teacher knowledge is grounded in knowledge from existing school practices and research (professional traditions); knowledge from being in the classroom (practical wisdom); and the prospective teacher's knowledge from being a learner of mathematics (learner knowledge). We see similar categories for the teacher educator. The classroom events (for the teacher) translate into maths ed sessions, the classroom settings in which teacher educators meet teachers; professional traditions here relate to knowledge from systems, institutions and culture, e.g., expectations to do research and publish; practical wisdom relates to knowledge from engagement with teachers in education-focused events. Here, teacher educators' learner knowledge is the

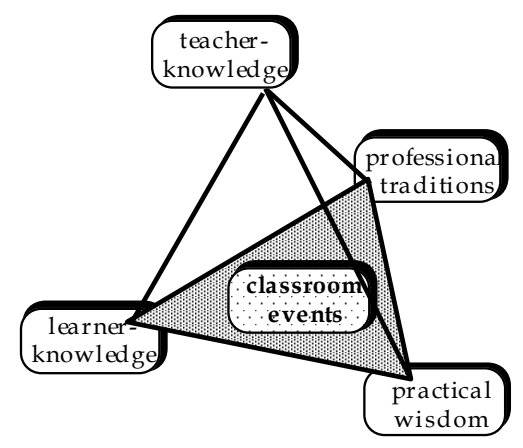

Figure 2a. Teacher knowledge

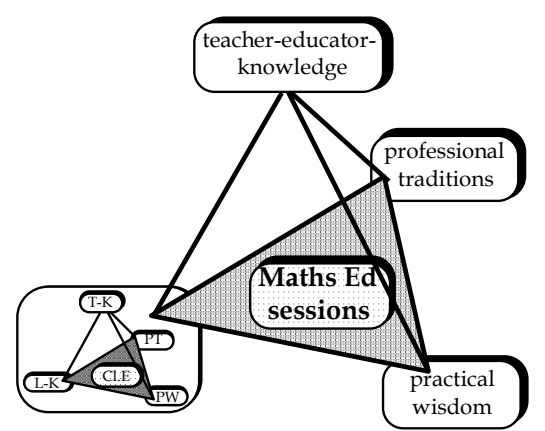

Figure 2b. Teacher educator knowledge 
knowledge they bring from having been teachers themselves and we see in the figure that this strand of knowledge brings with it the full complexity of teacher knowledge.

In the second model (Figure 3) we see two learning cycles: teachers as learners from tasks designed by teacher educators who facilitate teachers' learning and learn themselves in this process. The two cycles are interwoven and interdependent.

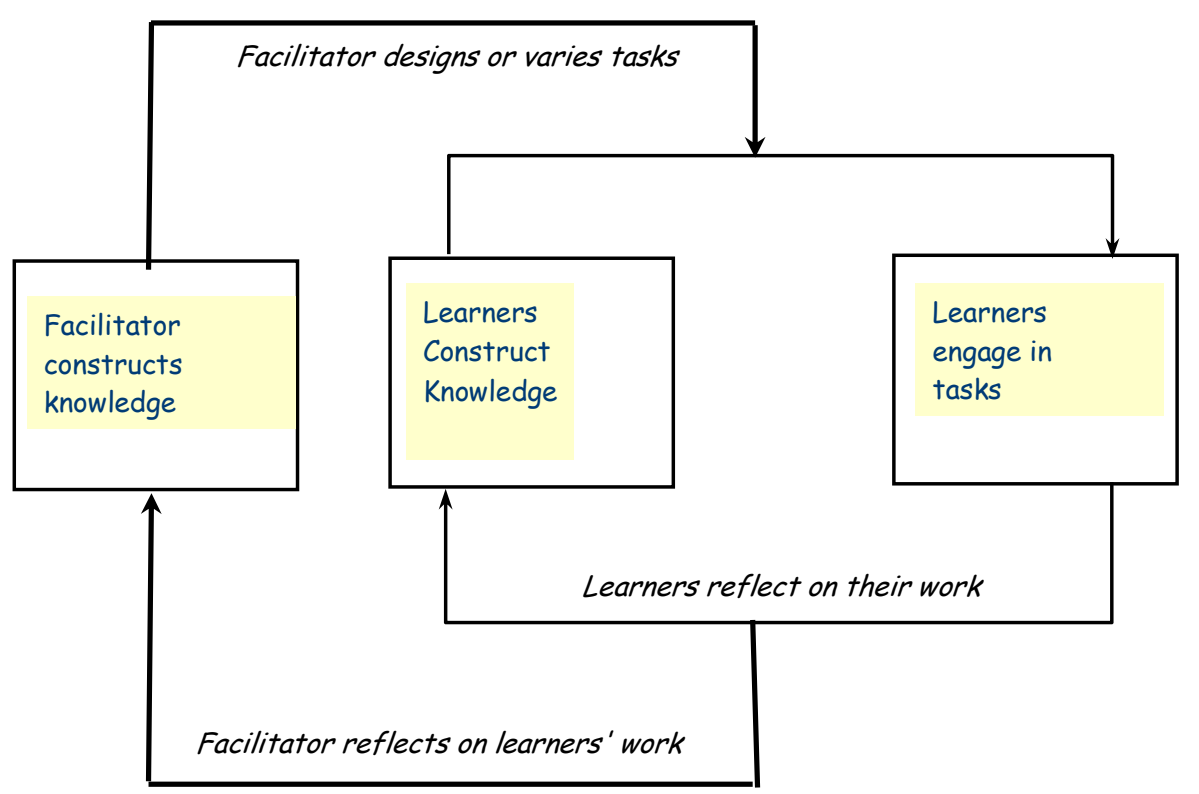

Figure 3. Task-based knowledge of teachers and teacher educators

In the first model (Perks and Prestage), we see teacher knowledge as a mediating factor for the development of teacher educator knowledge; in the second (Zaslavsky), the design and use of tasks for teachers' learning (itself drawing on specialist MTE knowledge) mediates the process of teacher educator learning. In expressing growth of knowledge as a mediational process, I am drawing here on a sociocultural theoretical frame rooted in Vygotsky (1978) and Leont'ev (1979) in which tools and signs are seen to mediate the learning process. Teacher knowledge and design and use of tasks can be seen as "intellectual tools" (Wartofsky, 1979, cited in Wells, 1999, p. 69) through which the MTE knowledge grows. Other models of learning can be theorised similarly: for example Victoria Sanchéz and Mercedes García [14] discuss dilemmas they face in their practice as teacher educators. The dilemmas arose from choices which had to be made from differing alternatives of equally perceived values. Through engaging with the arguments 
supporting each of the alternatives, the teacher educators deepened their own conceptions of the teacher education issues with which they were concerned and enhanced their own professional expertise. Thus the dilemmas acted as mediators for their learning. Razia Fakir Mohammad [8] shows how recognition of contradictory forces in her work with teachers led to her own enhanced knowledge in practice. Understanding the nature of these contradictions opened up possibilities to deal with the challenges in her practice. In each of these cases, we see teacher educators learning from their engagement in activity and their grappling with the issues it raised for them. Through participative activity with teachers, or in preparing for such activity, teacher educators begin to extract elements of generality which contribute to a synthesis of action and a theorising of action; in some cases a grappling with tensions and issues. The emergent theoretical models, as synthesised in the two examples above, offer a vision of practice in which complexity of practice can be seen holistically and from which new forms of practice can emerge.

Categorisations of teacher knowledge leading to MTEs' structuring of programmes for teacher or for MTE learning

While we might seek to identify teacher and teacher educator learning as growth of knowledge in practice in which holistic complexity is preserved, we desire nevertheless to make sense as teacher educators of the elements and processes of teacher learning in order that teacher learning can be fostered in our programmes and projects. Research and theorising over two decades and in recent times have sought to define or reveal elements of teacher knowledge which can lead to formulations of teacher education practice facilitating development of teachers' knowledge. Examples include Shulman's (1987) seven categories of teacher knowledge from which researchers in mathematics education have distilled examples of pedagogic content knowledge in distinction from either knowledge of mathematics or knowledge of pedagogy in mathematics teaching (e.g., Graeber \& Tirosh, in Volume 1 of this handbook), of mathematical knowledge for teaching (e.g., Ball and Bass, 2004) in distinction from mathematics knowledge per se, and of didactical knowledge (e.g., Winslow and Durrand Guerrier, 2007) to emphasise the didactical transposition from mathematical knowledge to knowledge for teaching mathematics.

Christer Bergsten and Barbro Grevholm [11] trace analytic approaches to distinguishing elements of teachers' knowledge in the MTE literature: for example the competency approach taken in the Danish KOM project in which eight specific competencies are identified (Niss, 2004). They comment on the report "Adding it up" (Kilpatrick, Swafford and Findell, 2001) in which mathematical proficiency is defined through five major strands. An aim in producing such distinctions is to develop in prospective or practising teachers each of these competencies or strands of proficiency, and a major question for mathematics educators is how to design programmes through which such competency or proficiency can emerge. 
Bergsten and Grevholm point to "the didactic divide": a gap between disciplinary and pedagogic knowledge, between theory and practice, observed in such programmes. It raises a question of how theory and practice can be linked in helpful and realistic ways for prospective teachers who rely on their programme to provide such links. Jaworski and Gellert (2003) point to four modes of programmes showing varying combinations of theory and practice with the ideal being a fully integrated model. In such a model, the timing of theoretically focused events and work in classrooms is such as to allow two-way reflections in which theory can be understood through practice and practice be informed by theory. However, such models are internationally much less common and harder to achieve from institutional perspectives than those which separate theory and practice.

Of important consideration in addressing the theory-practice divide in educational programmes is where and how teachers learn mathematics, or mathematics for teaching. In Volume 1 of this handbook, issues of teachers' knowledge for teaching mathematics are discussed, including what mathematics is needed for different levels of teaching. MTEs, must also address how their design of courses enables teachers to learn this mathematics. For example, there might be a distinction between courses which are primarily focused on mathematics and others with strong elements of pedagogy and didactics. Chapters from Amy Roth McDuffie, Corey Drake and Beth Herbel-Eisenmann [12] and Victoria Sánchez and Mercedes García [14] make explicit the thinking and choices of MTEs in distinguishing mathematical content from, or relating it to aspects of pedagogy and didactics for prospective elementary mathematics teachers. Sánchez and García distinguish a mathematics course for teachers from a mathematics methods course, discussing in detail the factors influencing what distinguishes such courses. Perks and Prestage [13], working with prospective secondary teachers, in a programme that is only one year in length, show how tasks that focus on methods of mathematics teaching can also promote deeper understanding of mathematical concepts. In each of these programmes, we see that the kinds of tasks designed by MTEs for teachers are often multipurpose tasks that address the deepening of mathematical knowledge alongside focuses on pedagogy and didactics. MTEs emphasise the importance for teachers of developing reflective attitudes to such distinctions through which complexity can be acknowledged and of providing opportunities for linking with school-based elements of the programme.

So far in this section, I have been focusing on elements of teacher knowledge relating to programmes designed by teacher educators for teachers. Designing of such programmes could be seen as expressed above as a mediating tool in development of MTE knowledge. However, can we see a parallel formulation in designating elements of MTE knowledge, leading to programmes designed for MTE development? And who should organise such programmes? Orit Zaslavsky [5] offers seven themes that reflect goals for mathematics teacher education, not based on the conventional content topics of teacher education such as teaching decimals or grouping practices, but which suggest the kinds of competency needed by MTEs in promoting teaching development. They include, coping with conflict, 
dilemmas and problem situations; selecting and using (appropriate) tools and resources for teaching; and sharing and revealing self, peer and student dispositions.

Such areas of competency form the content basis of a programme specially designed for the education of MTEs of practising teachers in Israel, the MANOR programme. In introducing this programme, Ruhama Even [3] points to a gap in the literature involving missing research on the education of teacher educators, the ill-defined nature of the field of educating practising teachers, and a lack of information on the practice of mathematics teacher educators. The MANOR programme (deriving from the Hebrew word MANHIM, meaning "guides") addressed this gap through its design, delivery and evaluation. It was led by experienced MTE researchers and drew its participants from a range of professional areas including teacher mentors, mathematics coordinators in schools and staff of curriculum implementation projects. The curriculum for the programme included three main areas of study captured under the broad headings of mathematics education, mathematics and teacher education. Ruhama Even coined a new word "knowtice" to designate the integration of knowledge and practice in the MANOR programme. It seems to me that the programme as described not only addresses the key areas of knowledge indicated in Figure 1, but comes close to the integrated form of programme suggested in Jaworski and Gellerts' four modes mentioned above. Important to this integration are elements of theory and research as part of which participants read the research literature, address theoretical concepts and produce their own written materials - itself a formative process about which I say more below.

In this section, I have drawn attention to categorisations of teacher knowledge in teaching mathematics and issues raised for MTEs in promoting teacher knowledge leading to MTEs' own learning. Categorisations offer a multiplicity of ways of cutting through the complexity of teachers' knowledge and of knowledge in teaching mathematics. MTEs' awareness of categorisations from reading the literature, in resonance with their own experiential knowledge can form a powerful knowledge base for the construction of programmes and projects in teacher education. The MANOR programme offers just one example, but as yet a unique example in terms of education of MTEs. In any such programme, choices have been made as to the topics to be addressed and modes of addressing them. Such choices are not straightforward, as Sanchéz and García have pointed out, and it is clear that MTEs learn particularly from grappling with dilemmas presented. However, despite considerable evidence of such learning in the research literature, Olive Chapman [6] points out that MTEs rarely speak about their own learning in reporting from research in their programmes - the focus being rather on what teachers have learned.

We see an exception here in the chapter of Amy Roth McDuffie, Corey Drake and Beth Herbal-Eisenmann [12] who together reflect on their teacher education programmes for prospective teachers and recognise ways in which they themselves have learned from these programmes. Making MTE learning in a teacher education programme more overt seems important to addressing how mathematics teacher 
education develops. An important question for MTEs seems to concern how their own growth of knowledge through engaging with literature on categorisation and subsequent grappling with the dilemmas of choice relates to the experiences and learning of teachers in the resulting programmes or projects. A further question, to which I return later in the chapter, is whether teachers might learn in similar ways given appropriate contexts.

\section{Perception, conception, attention and awareness}

Martin Simon [1] makes a distinction between teacher education programmes which have process goals only and those which have both content and process goals. He focuses particularly on the second category, programmes which have both content and process goals, and speaks of "courses or workshops for teachers in which teacher educators aim to promote particular mathematical and pedagogical concepts, skills and dispositions", perhaps based around categorisations such as are mentioned above. Simon suggests four areas of research-based knowledge that are currently insufficient for promoting desired (by the reform movement) concepts skills and dispositions. Drawing strong parallels between teachers' teaching of mathematics and teacher educators' teaching of mathematics teaching, he suggests that the insufficiency is one of understanding conceptualisation processes. Thus teachers, in seeking to promote mathematical understanding in pupils perceive what is required from pupils in terms of the mathematics to be understood, and they structure pupils' activity around such perception. Simon calls this a perception-based mode of thinking. It is teacherfocused rather than seeking out the conceptual position of the pupil. If a teacher alternatively takes a conceptual focus - seeking to understanding pupils' current conceptions - then attention can be given to how pupils can move to a higher conceptual level and what forms of activity can support and promote such a conceptual shift. This is described as a conception-based mode of thinking. Similarly, teacher educators may be caught up in a perception-based mode of designing teacher learning activities seeking to promote what the educator perceives as being required, rather than exploring first teachers' current conceptions and basing their programme on promoting conceptual shift. Simon grounds his conception-based perspective within a Piagetian theory of assimilation: the issue for teacher educators is how to promote a change in teachers' assimilatory structures. A first step is seen to involve research that illuminates these structures.

These issues and this challenge are addressed by Ron Tzur [7] who refers us to the learning paradox (LP) (e.g. Bereiter, 1985), an issue deriving from a constructivist notion of assimilation in reaching an understanding of a new concept. The issue concerns what (mental) mechanisms exist to promote construction of a concept that is more complex that those already assimilated. It appears that a student needs already to have some understanding of a concept prior to learning it, in order to allow concept construction. The LP presents a dilemma for teachers and educators taking a conception-based approach to promoting learning of declared concepts. Tzur, having himself grappled with this dilemma 
over many years, distinguishes intuitive and non-intuitive teaching: intuitive referring to following ones own intuitions to promote learning in others (a perception-based perspective), and non-intuitive involving an awareness of the LP and developing strategies to overcome it. Tzur traces his own learning as a teacher educator and offers a nested model of developing awareness: learning mathematics through teaching it; learning pedagogy through teaching teachers; learning teacher education through teaching prospective mathematics teacher educators (MTEs) and learning to mentor MTEs through scholarly collaboration and continual teaching. In each case the theoretical model is one of mental construction, the teacher or MTE's own mental construction of the concepts being taught and the strategies for teaching them, related to the mental constructions of the learners who are the focus of the teaching. The model has resonances of that offered by Perks and Prestage, although couched in constructivist theory while Perks and Prestage ground their work socioculturally. I return to such theoretical differences shortly.

Tzur relates his rationalization of these complex processes to Mason's psychology of awareness and attention. John Mason [2] starts from what might seem an obvious statement: "teachers cannot make learners learn, nor can they do the learning for their learners". Elsewhere (Mason, 2002, p. v), Mason makes the point "I cannot change others. I can work at changing myself". So, as teachers or MTEs, all we can do is "direct learners' attention", through tasks, activity and interaction designed to promote the learning we seek. Awareness develops from what we attend to at any time, and "if you put yourself in an unfamiliar situation, you may become aware that experts are attending to details unnoticed by novices". Thus, as teachers or MTEs, as a result of being aware of what contributes to our own learning, we can create situations finely attuned to learners' attention - "not only 'walking the talk' but 'talking the walk"'.

Mason emphasises the necessity of teachers and MTEs challenging themselves by working on elements of their practice - working on their own mathematics, or working on their own pedagogy and so on. In the spirit of this overt learning through experience, they become aware of tasks that can be especially fruitful in generating attention and promoting awareness. Such tasks can be offered to others with the possibility of generating learning outcomes. Orit Zaslavsky's chapter [5] takes these ideas further through an analysis of task development.

\section{The teaching problem}

Issues related to perception and conception, attention and awareness focus on the thinking of individuals and on ways in which attention is focused and awareness develops. Attention and awareness relate to the construing individual (although they can be seen as more socially based as I address below) whereas perception and conception relate to the complex process of conceptualising the construal of other individuals, the learners to whom teaching is directed by teachers and MTEs.

This brings into focus the relationship between teaching and learning from constructivist perspectives. Constructivism is a theoretical perspective addressing 
mental processing in coming to know, that is in the learning of the individual. Alternative ways of conceptualising learning are offered through a range of sociocultural theories in which knowledge is seen to grow through participation in social practice. Vygotsky $(1978$, p. 57) has written that learning is first of all in the social plane before being internalised to the mental plane. James Wertsch (1991) takes this further suggesting that rather than seeing mental functioning as deriving from participation in social life (a dualistic separation), "the specific structures and processes of intramental processing can be traced to their genetic precursors on the intermental plane (p. 27)". In other words, individual mental thought processes and functionings have their origins fundamentally in social interaction. Here we talk of learning, and not of teaching. Although scholars often extrapolate from theories of learning to consequences for teachers and teaching (in the term constructivist teaching for example), the links are not obvious.

Within a social frame, from a position of situated cognition and social practice theory (e.g., Lave and Wenger, 1991), Jean Lave challenges us as follows:

People who have attended school for many years may well assume that teaching is necessary if learning is to occur. Here I take the view that teaching is neither necessary nor sufficient to produce learning, and that the socio-cultural categories that divide teachers from learners in schools mystify the crucial ways in which learning is fundamental to participation and all participants in social practice. (Lave, 1996, p. 157)

We have seen above (with reference to the learning paradox) that the shift from theorising learning in constructivist terms to conceptualising teaching in such terms leads to problems. There are also problems in conceptualising teaching in sociocultural terms: if a teacher is supposed to enable others to learn, how can a teacher enable learning through participation? The issue here, relating to participation, a concept in sociocultural theory, parallels that of conceptualising construal of other individuals, those we would teach. In whichever theory we locate our conceptualisation, we propose models of learning, and experience shows us that learners do learn. However, we cannot readily use these theories to conceptualise the promotion of learning. Learners may not learn what teachers or MTEs want them to learn. Here is the crux of the teaching problem: what does it mean to get other people to learn what we want them to learn? Can learning theories address this (deceptively simple) question, and will any answers provided, according to different learning theories, differ?

I see this question as fundamental not only to Volume 4, but to this handbook as a whole. It concerns the agency of both teachers and MTEs in the learning processes respectively of students learning mathematics and teachers learning teaching mathematics. Three chapters in Volume 4 address this question from sociocultural perspectives. 


\section{Sociocultural views on teacher and MTE learning}

Perks and Prestage [13] root their model, discussed above, in Vygotskian theory. They see expertise not as located in the individual but as distributed across systems involving other people and the artefacts they use to mediate learning of scientific concepts - concepts developed through the context of instruction, including those in both mathematics and mathematics teaching. According to Vygotsky (1986), a scientific concept involves from the first a mediated attitude towards its object: mediation being provided by artefacts or social dynamics within a system. Distributed knowing refers to knowledge distributed across the people within a system, rather than knowledge located within the individual, or knowledge that is common to all. Different forms of expertise can be seen to be rooted in the practices in which experts are engaged and to which newcomers gain access. Here we think of practices of mathematics learning and teaching within systems of education and schooling. Such ways of thinking offer a sense of holding complexity through focusing on community and system in which activity takes place. Knowledge can be seen as situated in the practice with which activity is associated: students, teachers and MTEs learn as part of their engagement in communities of practice (Wenger, 1998) and the associated systems of which they are a part. Perks and Prestage write,

... not only do we as tutors have to develop as teacher educators, we have a limited time frame to work with prospective teachers on developing, in Vygotsky's sense, scientific concepts about teaching. Thus a major part of our development lies in looking for efficient and effective experiences to promote the learning of our prospective teachers.

They use activity theory (Cole \& Engeström 1993; Engeström, 1999), conceptualising the activity system as a learning zone, a system that allows for the learning of participants to contribute to the development of the system. This allows them to "trace connections between the acts that make up the action of learning about teaching in the activity systems of our current practices". I see here a sociocultural framing of the cognitive position articulated by John Mason regarding the drawing of a learner's attention to key concepts through suitably designed tasks which an expert recognises can educate awareness.

How sociocultural perspectives can contribute to our understanding of how learning takes place is also addressed by Merrilyn Goos [4] who draws on sociocultural theory to inform research and development interventions that aim to improve teachers' (and MTEs') opportunities to learn. Goos uses Valsiner's zone theory, extending Vygotsky's zone of proximal development (ZPD) to include two other zones: zone of free movement (ZFM) and zone of promoted action (ZPA). Together these zones, defined from the perspective of teacher (or MTE) as learner, include also indicators for intervention by those wishing to promote learning (the teachers of teachers, or of MTEs). Briefly, ZPD offers a set of possibilities for development influenced by learners' knowledge and beliefs in practice; ZFA can be interpreted as constraints within professional contexts, and ZPA as approaches 
that can engage with possibilities for development and promote actions that can be seen as viable within a given ZFM. Goos analyses initiatives in mathematics teacher education with respect to interaction between these zones, and extends her analyses to consider her own learning in relation to these perspectives on teacher learning. Thus, both Perks and Prestage, and Goos address and theorise the question of agency of the teacher or MTE promoting the learning of others and learning themselves as part of this process. In my next main section, I examine further the inter-relationship of these processes as I see it.

In the third chapter reporting research based in sociocultural theory, Simon Goodchild [10] extends Wenger's theory of community of practice to conceptualise teacher and MTE (didactician) learning as taking place reflexively within communities of inquiry. Teachers and didacticians together form a project community. Through participation in established communities of practice (school or university) teachers and didacticians use inquiry as a critical tool to promote learning within the project. Inquiry results in critical alignment with the norms of established practice, allowing teachers and didacticians to act within their practice while at the same time questioning its dynamics and exploring new ideas (Jaworski, 2006). An important aim of the project is the development of teaching to promote enhanced learning environments for pupils in mathematics, and didacticians aim to support teachers in this development. Goodchild draws on Paolo Freire's (1972) notion of conscientization, from a critical theory paradigm, to support the notion of critical alignment. Freire's conscientization, addressed as a challenge against poverty and oppression in the global human condition, is a metaphor for the condition of teachers (and MTEs) 'oppressed' in their practice by historic, economic, social and cultural contradictions over which they have little or no control. Inquiry as a tool, developing into inquiry as a way of being provides a means of critical action and associated growth of knowledge while working from within the conditions that impede action. The ideas relate strongly to the position on dilemmas articulated by Sánchez and García.

A difference between the programme discussed by Goodchild and the two earlier programmes in this section can be seen in relation to Martin Simon's distinction mentioned earlier. The project discussed by Goodchild would probably be located within Simon's first category of programmes that are process oriented, while the others have both content and process goals for prospective and/or practising teachers. The degree of agency exercised by the MTEs in these programmes is related to their responsibilities within their programme: in the first two programmes MTEs' would have a higher responsibility related to institutional settings, and their courses, curricula and assessment, than in the third, a research and developmental partnership between university and schools where goals of the programme could be mutually negotiated and defined. However, in all three we can see agency interpreted through a model of co-learning within institutional settings. I will return to this idea shortly. Next, however, I focus on moral and ethical questions for MTEs as they work within programmes and exercise agency in promoting learning for teachers and for themselves. 


\section{Ethical and moral perspectives in mathematics teacher education: caring and reciprocity}

The conceptualisation of teaching in relation to learning, and the practical realisations of such conceptualisation beg questions about the nature of relationships between learners and teachers, between teachers and MTEs, and between MTEs less or more experienced. Such questions can lead to moral and ethical considerations. What does it mean to take a moral or ethical approach to promoting mathematics learning and teaching development? The chapters in Volume 4 have offered a variety of perspectives relating to this question.

Paola Sztajn [15] discusses caring theory, delineating issues she attends to in becoming a caring mathematics teacher educator of practising teachers. Her caring theory derives from $\mathrm{Nel}$ Noddings work (e.g., 1992) and extends beyond caring for pupils in schools to caring for teachers in professional settings. Sztajn speaks of caring as a relational concept which plays out in the interactive setting involving carer and cared-for and with a reciprocal dimension. Thus it is not just a case of the MTE caring for the teachers with whom she works, but rather of the MTE taking responsibility to initiate a caring ethic through which mutual caring can result. Caring, contrary to popular perceptions of being cosy and comforting, is a cognitive construct with a critical dimension. As the carer seeks to understand the perspective and conceptions of the cared-for, the latter is drawn into a reciprocal perception of the carer's motives in promoting learning and insight into what is to be learned. In constructivist terms this reciprocal positioning addresses the learning paradox. In sociocultural terms it creates a mutual space in which reciprocal participation generates co-learning. Reciprocity allows both participants not only to respect the perspectives and position of the other, but commonly to seek to know how the other sees and thinks.

Relationships between teacher and didacticians in the project described by Simon Goodchild [10] can be seen to exemplify a caring ethic. Goodchild, drawing on Hostetler (2005), speaks of good research requiring ongoing attention to human well-being and going beyond the usual ethical consideration of avoiding risk or harm towards research that will be positively 'good' for participants. Beyond doing 'good' however, is the critical dimension mentioned above. A caring relationship affords inquiry and overt probing into normative processes. Through examples from her own practice, Sztajn shows that a caring attitude from one partner not only provides the partner with support, drawing on respect and trust from the other, to risk challenging new actions, but can work also in the other direction when the cared-for really tries to understand and achieve what the carer seeks to promote. In this way the agency of the carer is shared by the cared for. Goodchild, however, offers several examples where reciprocity is not achieved despite the good will of the didacticians and their critical agency.

This reminds us forcibly of the teaching problem and lack of ready solutions. Razia Fakir Mohammed [8], coming overtly from a moral position in which she desired to care for participants in her research was brought up against the lack of reciprocity when a teacher with whom she sought to work in a caring way 
challenged what she offered. An implication was that she had not understood sufficiently the issues the teacher faced in the institutional environment, and that what she seemed to propose could not work for him. It was clear that the caring relation had not established reciprocity and that the MTE's care for the teacher had not translated into the kind of action that could achieve developmental goals.

In his work in mathematics teacher education in the Western Pacific, Sandy Dawson [16] worked from an ethic of trust and respect in which he sought mutuality with his teacher and MTE colleagues in the Pacific region to promote and sustain development. Dawson describes aspects of culture in the communities of the Pacific very different from those he was familiar with, despite his considerable work with First Nations people in North America. Care showed itself in an overt willingness to know participants' views and feelings on the approaches he used, and to communicate his own nervousness and good will in using them. Reciprocity emerged when, despite considerable cultural differences, commonalities of purpose were recognised and his own aims and values were reflected in the words and actions of his partners.

Thus, we see in these chapters examples of reciprocity in which mutual caring relations seem to result in affective promotion of learning as conceived by the teacher or MTE, and others where reciprocity seems not to be achieved. Konrad Krainer [9] suggests that reflecting on learning is a two-way process: not only should MTEs ask teachers to reflect on their learning as part of a teacher education process, but the MTE should reflect also on his or her own learning: "we do not only demand activities from those for whose growth we are co-responsible, but we do it also ourselves". I infer from these words another aspect of a critical caring relation. As MTEs our agency is not just in the processes and tasks we offer to teachers and the kinds of engagement we seek from them. It rests also in overt demonstration of our own desires to fulfil ourselves the goals we suggest to them and our willingness to grapple with the challenges that arise - walking the talk.

\section{Growth of knowledge through reflection, inquiry, research and writing}

I quoted above from the words of Konrad Krainer: "we do not only demand activities from those for whose growth we are co-responsible, but we do it also ourselves". In the mathematics teacher education literature it is now extremely common to see MTEs encouraging teachers to reflect on their practice, and discussing reflection as a mediating artefact (not necessarily using these words) in teachers' learning. In this volume four chapters overtly (in Section II), and several others implicitly, offer MTEs' reflections on their own practice as MTEs. The form of what is offered is in some cases autobiographical as in Section II, and in others it is part of a rationale for theoretical perspectives espoused and/or ways of working developed by MTEs in their programmes. This differs from the literature more widely as powerfully emphasised by Olive Chapman [6] in her review of papers reporting from learning of teachers in programmes run by MTEs. Research findings in these papers constituted evidence of MTEs' learning: Chapman writes, "for the most part, this learning was presented as what other teacher educators 
could learn about the nature of these approaches to instruction rather than the actual learning of the persons conducting the research". When I was editor of JMTE, reading many submissions of this kind, I sometimes suggested to authors that they might like to reflect on how their findings from research had influenced their own thinking and impacted their own practice. In just a few cases, authors incorporated a few paragraphs to address this question, and some expressed that they had found it valuable to address the question which might not otherwise have become overt. When I invited certain potential authors to contribute to this volume of the handbook, a response I received said something like, 'but I have done no research into my own learning/practice as a teacher educator', implying that research into teachers' learning, or into programmes designed to generate teachers' learning, provides no evidence of MTE learning. Yet the findings of such research are manifestly what is learned from the research by the researchers who are MTEs.

I have shifted here from reflection to research; but is this such a big leap? In the 1980s and even earlier in some cases, in mathematics teacher education, we started to see programmes involving teachers as researchers, investigating, or inquiring into their own practice. In 1987, the Association of Teachers of Mathematics (ATM, 1987) in the UK published a booklet entitled Teacher is (as) researcher, emphasising the research-like nature of good teaching. In 1988, a working group was initiated at PME entitled Teachers as Researchers, and 9 years later, in 1997, a book Developing practice: Teachers' inquiry and educational change was published based on the work of this group (Zack, Mousely and Breen, 1997). Much of the research referred to in these two publications is described as "action research", and might be seen as a part of the wider action research movement that was growing internationally at that time. Stephen Kemmis, a leading member of this movement spoke of reflection as "meta thinking", thinking about thinking. He went on to say:

We do not pause to reflect in a vacuum. We pause to reflect because some issue arises which demands that we stop and take stock or consider before we act. ... We are inclined to see reflection as something quiet and personal. My argument here is that reflection is action-oriented, social and political. Its product is praxis (informed committed action) the most eloquent and socially significant form of human action (Kemmis, 1985, p. 141)

Kemmis conceptualised action research with reference to a critically reflective spiral of plan, act and observe, reflect (Kemmis and McTaggart, 1981; Carr and Kemmis, 1983). Thus, reflection, or critical reflection as is sometimes the term used, is central to a process of action research and related to conscientization as quoted by Goodchild from Friere.

MTEs researching their teacher education programmes might not consider they are engaged in action research. Action research is "insider research", that is research or inquiry conducted by practitioners into aspects of their own practice. This contrasts with outsider research in which 'outsider' researchers study the practices of others. It seems to me that MTEs researching their own programmes could be seen to be in either or both of these camps, and perhaps the distinction is 
not so clear anyway. However, Chapman's review indicates that research reports are usually couched in the language of the outsider rather than that of the insider. So, perhaps a critical factor is how as MTEs we talk about what we do (talking the walk?).

A major difference between insider and outsider research might be see in terms of the kinds of knowledge it generates: insider research linking to enhanced practitioner knowledge and concomitant development of practice; outsider research linking to academic analyses, publication in research journals and generalised knowledge for the research community. It may be the MTE researchers see themselves largely generating the latter kind of knowledge, and if so this seems a pity. It suggests that the former kind of knowledge is being neither celebrated nor even acknowledged. However, this distinction is becoming blurred as more projects are conceived of as partnerships between teachers and MTEs in which both kinds of knowledge are sought and valued. Chapters from Krainer and Goodchild in this volume speak of such projects, respectively IMST and LCM. Both projects have a fundamental concern to influence development and improve teaching and learning; thus growth of practitioner knowledge is central. Both perform academic analyses of data, systematically collected according to clear research questions, and offer generalised formulations for the research community. A question MTEs might address more overtly concerns the overtly symbiotic nature of these two forms of research and ways in which the resulting forms of knowledge are related (Jaworski, 2003). This might enable to us tackle better the problem of academic research papers sitting on shelves and not reaching the practitioners for whom the findings could be of value (e.g. Hargreaves, 1996).

It is an important responsibility for many MTEs to engage in research, keep up to date with the research literature, produce academic papers and publish in highly rated research journals. Those of us who do this recognise how much we learn from reading and writing: the challenge and indeed the struggle to formulate texts that fit the academic mould and do justice to our research and its findings. Several of the authors in this volume have spoken of the formative value of this writing process and of using writing as an educative task in teacher education. Ruhama Even writes,

Another opportunity to participate in the community of practice was the use of participants writings on the activities they conducted for practising teachers of mathematics a resources for other participants and other teacher educators.

Pat Perks and Stephanie Prestage write

Writing about the session deepened our ideas as we noted our reactions to the session and the power of the labels [used spontaneously by prospective teachers to identify key ideas that has arisen in the context of programme sessions]. The act of writing extended our learning as we accounted for what had happened in the session. The act of writing, a professional tradition and rule of our activity system, acted also as a tool for learning as teacher educators. 
After reading such remarks in early drafts of papers, I asked all authors to what extent they had found writing their chapter, or writing more generally a useful tool. Some of the responses I received said:

- Writing this chapter proved formative for me as it oriented a few changes in focus of attention and thus helped me elucidate the issues I was struggling to put in words so that others understand them.

- We think that the process of writing our chapter has allowed us three things:

- we have learnt a lot

- $\quad$ because of that, we have gone ahead in our personal development

- $\quad$ in addition, we have felt members of an international community of practice/inquiry, since a lot of people have collaborated with us in the discussion of our ideas, improving of our English, etc.

- I find that writing is an opportunity to allow associations to flow more fully than is the case in presentations, where time is short and attention needs to be restrained. What can be done in a live session is to work with the audience's attention. What can be done in or through writing is to explore connections, and then to try to massage that into a coherent narrative which gives at least a flavour of the possibilities availabe to be pursued.

Konrad Krainer [9] points to writing as a valuable process for teachers, who acknowledge it despite the difficulties it caused them.

Evaluations showed that writing was a tremendous challenge for many teachers; however, at the end, when the studies had been written, mostly positive feelings and views remained. Only recently, a doctoral student (Schuster, in preparation) began to investigate the impact of mathematics and science teachers' writing on their motivation and competences.

Thus, the challenges and mediational structures for MTEs can work similarly also for teachers. We might explore more overtly the parallels between MTE learning and teacher learning and the value of collaborative approaches that encourage recognition of co-learning potential.

\section{MATHEMATICS TEACHER EDUCATORS - WHO ARE WE?}

\section{Teaching as mentoring}

The themes and issues discussed above point to the complexity of interrelationships between the learning of pupils, teachers and teachers educators, with which I have personally grappled for many years (e.g. Jaworski, 2001). In a recent paper, in which I referred to a developmental project in which I have been involved 
with co-researchers including teachers, I raised three questions about "layers of attention":

We are interested in developing the teaching and learning of mathematics so that pupils have better opportunities to learn mathematics with understanding and fluency. We see this involving three layers of attention:

- How can teachers and pupils create a mathematical environment in their classrooms with suitable opportunity for pupils to learn mathematics with understanding and fluency?

- How can didacticians and teachers create a didactical environment in their interactive space (in schools and college) with suitable opportunity for teachers to develop mathematics teaching with understanding and fluency?

- How can xxxxxxx and didacticians create a (supra-didactical?) environment ... with suitable opportunity for didacticians to learn (didacting?) with understanding and fluency (Jaworski, 2007, p.6)

The third question is deliberately strange, to draw attention first to its parallels with the two earlier questions, but then to recognise that there is no (obvious) mentor for didacticians (MTEs) in the way that MTEs mentor teachers and teachers mentor students. We MTEs however, do need such mentoring. For example, in writing this chapter for the handbook, I asked my fellow editors to offer me a critical review to help improve the chapter. Our submissions of articles to journals results in a form of mentoring from our colleagues in the field who review papers and produce critical comments. In every case where this has happened for me, the paper produced as a result of working on the critical comments is a better paper than it would have been without this mentoring. The process of writing the paper is formative as expressed above, and the review process provides an important critical dimension. Both are mediating tools in crafting the written product and importantly in the associated learning that takes place. In a critical review of a draft of this chapter, Dina Tirosh made the comment:

Reading as a critical friend (under four different occasions - reviewing a paper, reviewing as an editor, reviewing as a critical friend and reading the works of my graduate students) differs from reading for the sake of reading. Such processes are important for our own growth. You mentioned in your chapter the contribution of the critical friends to the development of the papers - but, as we know, the readers also develop through doing this type of work.

This comment amplifies further the concept of reciprocity discussed earlier.

Martin Simon points to MTE education through PhD programmes in which $\mathrm{PhD}$ students focus their research on aspects of teacher and/or pupils' learning in teacher education programmes with which they are associated. The research process in which they engage and their supervision from more experienced MTE researchers offer forms of mentoring that lead to growth of knowledge in teacher 
education. The supervisors also learn reciprocally from their activity in this process. In the MANOR programme, Ruhama Even shows that prospective MTEs engage in tasks designed by their mentors (more experienced MTEs) which include reading, writing and critical reviewing. Such tasks are designed to draw new MTEs into MTE culture, from which they become legitimate (less peripheral) participants (Lave and Wenger, 1991).

I am using here the term mentoring, rather than the more familiar teaching to emphasise the facilitative role of the teacher or MTE. In the above we see three modes of mentoring

1) Actions of human agents, acting as critical friends - the teacher figure promoting learning of others

2) Actions of human agents in practice influencing their own development through some form of "inner mentor".

3) Actions of human agents working collaboratively together, mentoring for each other - "co-mentoring" (Jaworski and Watson, 1994).

These three modes, for the MTE are a part of 'normal' process. The culture of MTE activity is such that we take for granted that we will act in certain ways for our own development - in many respects we see it just as doing our job, not, overtly, as developing as an MTE. The seminars we attend and professional conversations we hold are part of that activity. When we act as mentors for our colleagues, either informally as critical friends or more formally, as reviewers for a journal, or as supervisors of $\mathrm{PhD}$ research, we enter into a didactical practice that is an extension of our ordinary norms of practice.

\section{Mentoring versus instruction}

Here I discuss MTE learning and development through engagement in a professional community in which participants are agents for their own and others' development. Part of the practice which develops is their working with teachers for teacher and teaching development. To what extent is this a mentoring process in the spirit of the discussion above and to what extent is it instruction? And are mentoring and instruction different? For example, are MTEs mentors in the programmes that Martin Simon refers to as having only process goals, whereas they are instructors in those which have content and process goals, when there is a content to be delivered? And, what are the parallels for teachers? Is there a culture in teacher development that parallels that described for MTEs - that is seen as just part of teachers doing their job - developmental agency as part of being a teacher? To what extent are, or can teachers be mentors for teachers? There are many programmes currently in which teachers mentor prospective teachers, with or without MTE counterparts (e.g., Jaworski and Gellert, 2003; Van Zoest and Bohl, 2002). In some cases, teachers are "trained" to become mentors as part of the programme. My use of the term "trained" suggests that some form of instruction is involved. 
Mostly for teachers, the content they teach is mathematics, although teachers as mentors for prospective teachers teach "teaching mathematics". MTEs teach "teaching mathematics" rather than, or as well as mathematics per se (e.g., Sánchez and García [14] - see comments above). Does the nature of teaching - as mentoring or instruction - depend on what content is being taught? Particularly, if mathematics is being taught, are we more likely to think in terms of instruction? What would it look like to characterise teaching mathematics (per se) as a mentoring process?

Recall Martin Simon and Ron Tzur's constructs "conception-based" and "nonintuitive" - these deal with the individual mentor who works to overcome the constructivist learning paradox - how the critical friend can enter into the conceptions of the mentee in order to provide support that really interacts with the thinking and needs of the mentee. Caring reciprocity can be similarly conceptualised. Recall John Mason's - I can only do the learning for myself, but through that learning I can notice what tasks are fruitful to generate awareness and offer these to others - and what the expert sees is different from the novice. Both of these perspectives deal with instruction in that they have predetermined goals for the learning of others. However, a key element of the associated didactics is that instruction is designed to work with learners' conceptions using tasks or other tools, not to try to take learners to where the instructor wants them to be by the route favoured by the instructor. Nevertheless, in this mode, there is inevitably a factor of "where the instructor wants them to be" and this factor can lead to a direct instruction, or a perception-based approach.

\section{Theory offering a frame on practice}

Having worked for many years myself within a constructivist frame (e.g. Jaworski, 1994), I have become increasingly aware that I need an alternative frame to make sense of some of the contradictions that become evident in such theorising, and to take account of culture and context as it is related to the overall complexity of the didactic process. The zone theory of which Merrilyn Goos writes, and activity theory as used by Pat Perks and Stephanie Prestage, both offer such an alternative. Over recent years, along with my colleague Simon Goodchild, I have begun to work with activity theory (e.g., Jaworski and Goodchild, 2006) to make sense of the complexity of learning processes as delineated in the three layers of attention at the start of this section.

Goodchild (2007) has analysed the activity of didacticians in the LCM project of which he writes in his chapter in this volume. Using an activity theory frame, based in the extended mediational triangle of Yrio Engeström (1999; see also Perks and Prestage [13]), Goodchild (2007) suggests there are two different activity systems in the LCM project. One activity system is that of the didacticians, based in university practice, taking an MTE role that includes explicit mentoring of teachers as well as personal development within the didacticians' community. The other system is that of the teachers in the project, based in school practice, working within the established communities of school and educational system to promote 
learning of pupils. Both teachers and didacticians are committed also to a project community that strives to develop inquiry in designing for and acting in the classroom to promote pupils' mathematical learning. Goodchild's findings suggest that the two systems exist side by side with interaction, but participation in the established communities is a stronger influence on activity than in the fledgling project community.

Taking the notion of two activity systems acting side by side - teachers in established school environments and didacticians in established university environments - with interaction as part of the project, I see mentoring relationships as expressed in Figure 4. Cells 1 and 4 express reciprocal learning (caring?) relationships within each of the two systems. Cells 2 and 3 express cross-system relationships. In Cell 2, we might see a relationship that carries instructional connotations, although there is no direct instructional intention involved. In Cell 3, although we might say there is no expressed intention for teachers to mentor MTEs, the nature of the project and its theoretical grounding in inquiry encourages teachers to speak out critically within the project and MTEs to analyse the meaning and impact of teachers' critical remarks for their development of practice. The table can be extended to include students in classrooms, but I leave that to the reader.

\begin{tabular}{|l|l|l|}
\hline $\begin{array}{l}\text { Mentoring } \\
\text { relations }\end{array}$ & \multicolumn{1}{|c|}{ Teachers } & \multicolumn{1}{c|}{ MTEs } \\
\hline Teachers & $\begin{array}{l}\text { Teachers mentoring } \\
\text { teachers within their own } \\
\text { community and system (1) }\end{array}$ & $\begin{array}{l}\text { Teachers mentoring MTEs } \\
\text { across the two activity } \\
\text { systems (3) }\end{array}$ \\
\hline MTEs & $\begin{array}{l}\text { MTEs mentoring teachers } \\
\text { across the two activity } \\
\text { systems (2) }\end{array}$ & $\begin{array}{l}\text { MTEs mentoring MTEs } \\
\text { within their own community } \\
\text { and system (4) }\end{array}$ \\
\hline
\end{tabular}

Figure 4. Mentoring relations within a developmental research project involving teachers and MTEs.

A very important outcome for the didacticians has been the steadying factor of the established school community and schooling system, informing and putting the brakes on didactic zeal - making clear the limitations on what it is possible to achieve and forcing a more practically-based didactic rationale. Although Goodchild's (2007) paper suggests a deficiency of developmental outcome in an apparent lack of expansive development, it seems to me that the project has achieved a great deal by creating a project community in which teachers can act as described, mentoring MTEs in terms of wider systemic factors that are highly influential on what is possible in classrooms and the interpretation of inquiry-based design and instruction in schools and classrooms. Recalling Figure 1, I talked of MTEs influencing growth of knowledge in B and C, drawing on their knowledge developing through research in A. I want now to express this from a teacher direction: teachers draw on their knowledge in practice in $\mathrm{B}$ and $\mathrm{C}$ (facilitated by 
the LCM project community) to act as agents for each other and in their own development in school settings. Their activity within the project impinges on MTEs knowledge in B, leading MTEs to question theoretical knowledge in A and reformulate associated didactical practice. The associated activity systems are both essential to the process described and the project acts as a catalyst, or a mediational tool in promoting learning within the established settings.

The LCM project was a developmental research project with process goals (Simon, this volume). It did not have content goals, for example in teaching mathematics or in teaching mathematics teaching. It did not involve courses for teachers or aim that teachers would learn specific elements of mathematics, pedagogy or didactics. Thus, it was set up to seek to create a project community in which partnerships between teachers and MTEs could be constituted democratically and principles of equity achieved. Such goals for the project were not achieved in quite the ways they were envisaged in conceptualisation (Jaworski, 2005). However, the resulting project allowed for the kinds of interaction I have described above. In the project that has succeeded LCM (TBM - Teaching Better Mathematics) teachers and their leaders from the school system have an overt part in planning activity together with didacticians ${ }^{4}$. It is hoped that this might lead to elements of "content" to be offered to teachers in ways designed to address systemic factors from the school community and in ways which build on MTEs' goals of practice expressed in the inquiry-based goals of the project community. The ground work in developing community between teachers and didacticians, the growing dialogue and language in which to talk to each other at meaningful levels allows content activity to be situated and take on new meanings. Thus, the processbased programme can lead to a fruitful base for more content-related work. I believe that these ideas are generalizable to programmes more widely, providing that we see teaching as more than just an instructive process with perceptual goals.

I used here the word "we". When I asked in my heading of this final section "who are we?" this provided an opportunity to see ourselves, MTEs, as partners with teachers, drawing reciprocally on distributed forms of knowing and providing reciprocally for the needs we identify jointly. For me, this seems a potentially fruitful way ahead.

\section{NOTES}

1 Teachers' knowledge in teaching is the focus of the first volume of this handbook: Sullivan, P., \& Wood, T. (Eds.). (2008). International handbook of mathematics teacher education: Vol. 1 Knowledge and beliefs in mathematics teaching and teaching development. Rotterdam, The Netherlands: Sense Publishers.

${ }^{2}$ Examples include practices evident in current literature such as CGI (Cognitively Guided Instruction) use of examples of student thinking as a basis for developing teachers thinking (e.g., Carpenter, Fennema, Peterson and Carey, 1988)); lesson study where teachers plan lessons together and learn individually from the joint process (e.g., Fernandez and Yoshida, 2004); use of video cases in which video acts as a tool to promote new ways of seeing and support individuals in developing teaching (Sherin, 2002; Nemirovsky, Dimattia, Ribiero and Lara-Meloy, 2005). Volume 2 of this handbook 


\section{DEVELOPMENT OF THE MATHEMATICS TEACHER EDUCATOR}

describes many, related tools and processes, including using narratives, cases, lesson studies, videos, CGI: Tirosh, D \& Wood, T. (Eds.). (2008). International handbook of mathematics teacher education: Vol. 2 Tools and Processes in Mathematics Teacher Education. Rotterdam, The Netherlands: Sense Publishers.

${ }^{3}$ When I refer to authors of chapters in this volume, I include their chapter number as written here [13].

${ }^{4}$ See also the chapter by Jaworski in Volume 3 of this handbook: Krainer, K. \& Wood, T. (Eds.). (2008). International handbook of mathematics teacher education: Vol. 3 Participants in mathematics teacher education: individuals, teams, communities and networks. Rotterdam, The Netherlands: Sense Publishers.

\section{REFERENCES}

Association of Teachers of Mathematics (1987). Teacher is/as Researcher. Derby: ATM.

Ball, D. L., \& Bass, H. (2004). Knowing mathematics for teaching. In R. Stræsser, G. Brandell, B. Grevholm, \& O. Helenius (Eds.), Educating for the Future. Proceedings of an International Symposium on Mathematics Teacher Education (pp.159-178). Stockholm: The Royal Swedish Academy of Sciences.

Bereiter, C. (1985). Toward a solution of the learning paradox. Review of Educational Research, 55(2), 201-226.

Carpenter, T., Fennema, E., Peterson, P., \& Carey, D. (1988). 'Teachers' pedagogical content knowledge of students' problem-solving in elementary arithmetic.' Journal for Research in Mathematics Education, 19, pp. 385-401.

Carr, W., \& Kemmis, S. (1986). Becoming critical: Education, knowledge and action research. London: Routledge Falmer.

Carter, R., \& Richards, J. (1999). Dilemmas of constructivist mathematics teaching: Instances from classroom practice. In B. Jaworski, T Wood, \& S. Dawson (Eds.), Mathematics teacher education: Critical international perspectives (pp. 69-77). London: Falmer Press.

Cole, M., \& Engeström, Y. (1993). A cultural-historical approach to distributed cognition. In G. Salomon (Ed.), Distributed Cognitions: psychological and educational considerations, (pp. 1-46) Cambridge, Cambridge University Press.

Engeström, Y. (1999). Activity theory and individual and social transformation. In Y. Engeström, R. Miettinen \& R-L Punamäki (Eds.). Perspectives on activity theory (pp. 19-38). Cambridge: Cambridge University Press.

Fernandez, C., \& Yoshida, M. (2004). Lesson study: A Japanese approach to improving mathematics teaching and learning. Mahwah, NJ: Lawrence Erlbaum.

Freire, P. (1972). Pedagogy of the oppressed. Harmondsworth UK: Penguin.

Goodchild, S. (2007). Inside the outside: Seeking evidence of didacticians' learning by expansion. In B. Jaworski, A. B. Fuglestad, R. Bjuland, T. Breiteig, S. Goodchild., \& B. Grevholm (2007). Learning communities in mathematics, pp. 189-204. Bergen, Norway: Caspar Forlag.

Hargreaves, D. (1996). Teaching as a research-based profession: Possibilities and prospects. Teacher Training Agency Annual Lecture. London: Teacher Training Agency.

Hostetler, K. (2005). What is "good" educational research? Educational Researcher, 34(6), 16-21.

Irwin, K. C., \& Britt, M. S. (1999). Teachers' knowledge of mathematics and reflective professional development. In B. Jaworski, T Wood, \& S. Dawson (Eds.), Mathematics teacher education: Critical international perspectives (pp. 91-101). London: Falmer Press.

Jaworski, B. (1994). Investigating mathematics teaching: a constructivist enquiry. London: Falmer Press. 


\section{BARBARA JAWORSKI}

Jaworski, B. (2001). Developing Mathematics Teaching: Teachers, Teacher-Educators, and Researchers as Co-Learners. In F-L Lin and T. J. Cooney (Eds.) Making Sense of Mathematics Teacher Education,pp 295-320. Dordrecht, The Netherlands: Kluwer

Jaworski, B. (2003). Research practice into/influencing mathematics teaching and learning development: Towards a theoretical framework based on co-learning partnerships. Educational Studies in Mathematics 54, 249-282.

Jaworski, B. (2005). Learning communities in mathematics: Creating an inquiry community between teachers and didacticians. In R. Barwell \& A. Noyes (Eds.), Research in Mathematics Education: Papers of the British Society for Research into Learning Mathematics, volume 7 (pp. 101-119). London: BSRLM

Jaworski, B. (2006). Theory and practice in mathematics teaching development: Critical inquiry as a mode of learning in teaching, Journal of Mathematics Teacher Education, 9(2), pp.187-211.

Jaworski, B. (2007). Developmental research in mathematics teaching and learning: Developing learning communities based on inquiry and design. In P. Liljedahl (Ed.) Proceedings of the 2006 Annual Meeting of the Canadian Mathematics Education Study Group, University of Calgary, pp. 316. Burnaby, BC: CMESG

Jaworski, B., \& Gellert, U. (2003). Educating new mathematics teachers: Integrating theory and practice, and the role of practising teachers. In A. J. Bishop, M. A. Clements, C. Keitel, J. Kilpatrick, \& F. K. S. Leung (Eds.), Second international handbook of mathematics education (pp. 829-9875). Dordrecht, The Netherlands: Kluwer Academic Publishers.

Jaworski, B., \& Goodchild, S. (1996). Inquiry community in an activity theory frame'. In Proceedings of the 30th Conference of the International Group for the Psychology of Mathematics Education (Vol. 3, pp. 353-360). Prague, Czech Republic: Charles University.

Jaworski, B. \& Watson, A. (Eds.) (1994). Mentoring in Mathematics Teaching. London: Falmer Press.

Jaworski, B., \& Wood, T. (1999). Themes and issues in inservice programmes. In B. Jaworski, T Wood, \& S. Dawson (Eds.), Mathematics teacher education: Critical international perspectives (pp. 125147). London: Falmer Press.

Kemmis, S. (1985). Action Research and the Politics of Reflection. In D. Boud, R. Keogh, and D. Walker (Eds.) Reflection: Turning Experience into Learning. London: Kogan Page.

Kemmis, S. \& McTaggart, R. (1981). The action research planner. Geelong: Deakin Univesity

Kilpatrick, J., Swafford, J., \& Findell, B. (Eds.) (2001). Adding it up: Helping children learn mathematics. Washington DC: National Academy Press.

Lave, J. \& Wenger, E. (1991). Situated Learning: Legitimate Peripheral Participation. Cambridge, MA Cambridge University Press.

Lave, J. (1996). Teaching as Learning, in Practice. In Mind Culture and Activity, 3(3), pp. 149-164.

Leont'ev, A. N. (1979). The problem of activity in psychology, In J. V. Wertsch (Ed.), The concept of activity in Soviet psychology (pp. 37-71). New York: M. E. Sharpe.

Mason, J. (2002). Researching your own classroom practice. London: Routledge Falmer.

Nemirovsky, R., Dimattia, C., Ribiero, B., \& Lara-Meloy, T. (2005). Talking about teaching episodes. Journal of Mathematics Teacher Education, 8, 363-392

Niss, M. (2004). The Danish KOM-project and possible consequences for teacher education. In R. Stræsser, G. Brandell, B. Grevholm, \& O. Helenius (Eds.), Educating for the Future. Proceedings of an International Symposium on Mathematics Teacher Education (pp.179-190). Stockholm: The Royal Swedish Academy of Sciences.

Noddings, N. (1992). The challenge to care in schools. New York: Teachers College Press.

Piaget, J. (1950). The psychology of intelligence. London: Routledge and Kegan Paul.

Sherin, M. G. (2002). A balancing act: Developing a discourse community in a mathematics classroom. Journal of Mathematics Teacher Education, 5, 205-233

Shulman, L. (1987). Knowledge and Teaching: Foundations of the New Reform. Harvard Educational Review, 57(1), 1-22.

Van Zoest, L. R., \& Bohl, J. V. (2002). The role of reform curricular materials in an internship:n The case of Alice and Gregory. Journal of Mathematics Teacher Education, 5, 265-288 
DEVELOPMENT OF THE MATHEMATICS TEACHER EDUCATOR

Vygotsky, L. S. (1978). Mind in society. Cambridge MA: Harvard University Press

Vygotsky, L. (1986). Thought and Language. Cambridge MA: MIT.

Wartofsky, M. W. (1979). Models, representation and scientific understanding. Boston: Reidel

Wells, G. (1999). Dialogic inquiry: Toward a sociocultural practice and theory of education. Cambridge, UK: Cambridge University Press.

Wenger, E. (1998). Communities of practice: Learning, meaning and identity. Cambridge, UK: Cambridge University Press.

Wertsch, J. V. (1991). Voices of the mind. Cambridge MA.: Harvard University Press.

Winsløw, C., \& Durrand-Guerrier, V. (2007). Education of lower secondary mathematics teachers in Denmark and France. Nordic Studies in Mathematics Education, 12(2), 5-32.

Zack, V., Mousley, J., \& Breen, C. (1997). Developing Practice: Teachers' Inquiry and Educational Change. Geelong, Australia: Centre for Studies in Mathematics, Science and Environmental Education, Deakin University.

\section{Barbara Jaworski}

Mathematics Education Centre

Loughborough University 